\title{
Reconstruction of Western Civilization Viewed by Sayyid Abû al- asanas' Alî al-Ḥasanî al-Nadwî
}

\author{
Sori Monang \\ Social Science Faculty, Islamic University of North Sumatra (UINSU), Medan, Indonesia \\ Sorimong85@gmail.com
}

\begin{abstract}
Nadwî has a "myriad" concept, both in written form and in the practical form of everyday life that is large enough to solve the social-theological problems that are being colonized by today's Western civilization. Western education led to the frost and decline of morality due to the loneliness of spiritual decline. Al-Nadwî also gave various analyzes that Western Education orientation is a lot of material, wants a high position and earn a large salary without implanting spiritual value. Secularization is a political movement, and in the history of this political movement was introduced by the West to strengthen its existence as an invader of civilization.
\end{abstract}

Keywords: Al Quran; western civilization; secularism; Moslem

\section{INTRODUCTION}

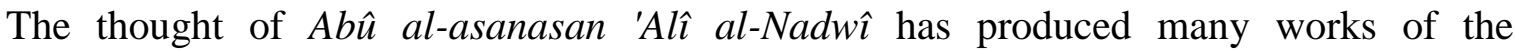
recognized theology of the' Ulamā, the people of the whole world make the book al-Nadwî as a reference in various disciplines. The works of al-Nadwî have been translated into various languages of the world such as into English, Persian, Urdu, Arabic, Hindi, and even into the Indonesian language. Al-Nadwî has succeeded in opening the narrow view of the Muslim world leader who considers that the material wealth possessed by European society is everything, and 
the best and the top priority. while they are dry and untouched within the context of thought and insight. With his keen insights from al-Nadwî̀'s thought it succeeded in bringing in a very useful thought to expel and save mankind from the modern Jahiliyah environment to the shade of Islam. As al-Nadwî nukilkan, that only Muslims are worthy to govern this world. Without Islam the world will face suffering and loss even though humans have all the sophistication and ease of life.

Through his work, Abû al-Hasan Alî al-Nadwî wants to re-awaken Muslims, that they are not actors of a staged play. However, they are the main factors that determine the face of the world. He said it was time for Islam to lead the world again, as Islam has saved the world in the 7th century AD with the coming of Prophet Muhammad saw. The Arab world according to Abû al-Hasan al-Nadwi is the hope of the Islamic world to lead the world once again, because they are the wombs that once gave birth to Islamic heroes who opened the gates of the world. Other works of his book are titled "Mukhtarat fî Adab al-'Arab, Qașaș an-Nabiyyin, Al-Qira'ah arRashîdah, Ilâ Mumaśsilî al-Islâmiyyah" and others. His latest work is the result of his lectures delivered in a congress in Asia and in New Delhi at the invitation of Pandit Jawaharlal Nehru. The lecture he wrote was then very popular in the Hijáz and Arab areas of the time. Much of his work was born through his participation in various national and international scientific

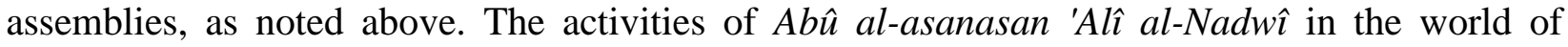
Islamic journalism are also numerous, such as in al-Diyâ' and al-Nadwah Magazines, published by Nadwah al-'Ulamâ, al-Muslimûn in Damascus, Al-Ba'aśal-Islâmî, Ta'mir Hayât and many more, both Arabic, English, Persian, Hindi, and Urdu. Al-Nadwî has a high awareness in understanding the social conditions of society today with various approaches, among the most important is; First, his skill in reconstructing the classical era against modern times. So in some of the books he wrote there were comparison between the lives of the Rasîl, the comparison, the Tabi'în, the clerics to then take the values contained therein to live in the present life; Second, his skill in reading the conditions of society-especially Muslims-today with various social criticisms, such as he often advocated the importance of the mastery of science and the dominance of the political movement in building a good civilization; Third, in the midst of the modernization of 
civilization al-Nadwî has a high spiritual awareness. In addition to promoting social movements in an effort to get closer to Allah as mentioned above, he still "upholds" Sufistic values (tasawwuf) in fortifying the Muslims from the influence of modern "Jahiliyah" today. Genealogically -social, al-Nadwî had a very important influence in the midst of society in his day. Not only to the neighboring people, but also in general for Muslims around the world. The influence is also easily visible from the influence of his thought, especially for his students through the process of education or through his writings; and also the influence is seen from the movement that he did for the civilization "India" at that time.

\section{REVIEW OF LITERATURE}

Abû al-Hasan al-Nadwî is a mausole or encyclopaedic figure. His mastery of Islamic scholarship, philosophy and insight of the movements of Muslims in various countries support his works accepted by Muslims in general. A total of 187 book titles in various Islamic thought

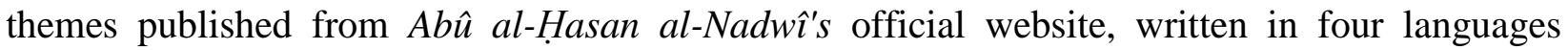
Arabic, Urdu, Persian, and English have been produced, is one of the forms of attention of alNadwî to the Ummah Islam. Not only Muslims in India, but all Muslims in the world. His contemporary lifetime with the Turkish collapse of 'Usmânî and the era of European colonization to various regions of Islam, both in Asia and Africa have made him always eager to call for the Islamic spirit to Muslims in the world. Abû al-Hasan al-Nadwî during his life much touched the side of $D a^{\prime} w a h$.

By studying the $d a^{\prime}$ wah approach of earlier scholars such as Imâm al-Sirhindi and Maulana Ilyâs as well as some Islamic figures, Shaykh Abû al-asanas al-Nadwî has brought a comprehensive $d a^{\prime} w a h$ and tarbiyah manhāj by combining several manhajj and approaches, into a combination in between an old Islamic movement that blessed with a useful application system. According to al-Nadwî understanding of the fundamentals of theology and $d a^{\prime} w a h$ will make a preacher really preach for Allâh swt., Not for personal interest, group or other. The principle that needs to exist is to preach for the good of the people wholly not for group or personal gain. The 
foundations laid down by al-Nadwî in carrying out the da'wah are the basic principles of "alTasallub fî̀ al Usûl" which is firmly in principle and "Al-Murûnah fî al-Wasâil" ie application in

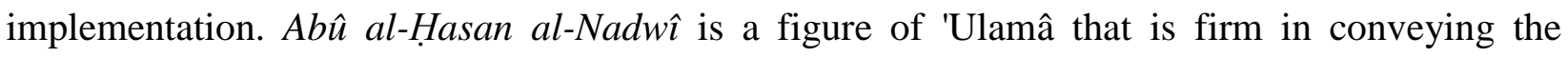
sentence of truth, so al-Nadwî much admired by the Islamic world and gained homage from the western world especially in Europe. Many invite lectures and seminars that al-Nadwî received from leading institutions in Europe such as in Geneva, Paris, Cambridge, Oxford, Glasgow, Edinburgh, and Spain. In the environment of the preachers and those involved in education, both in the East and in the West recognize this character. By reading the books of al-Nadwî it will be felt that al-Nadwî is our teacher who sits together. Abû al-Hasan al-Nadwî is also very concerned with the education system and many criticize the orientalist who distort the facts about Islam. In terms of religious factors, the goal of orientalist is to spread Christianity and try to explain its superiority over Islam. In addition, they try to arouse a sense of pride in their beliefs in the souls of young Muslims. After almost all his life was spent with the journey of science and da'wah calling on Muslims to return to the Qur'an and sunnah, then on Friday, 23 Ramadhan $1420 \mathrm{H} /$ December 31, $1999 \mathrm{AD}$, he died as he was preparing for performing the Friday prayers at his residence, when he was 85 years old. In remembrance of his services for the sake of religion, the prayer has been performed with prayer in the two holy land in the Mosque of al-Haram Makkah al-Mukarramah and Nabawî Mosque in Madinah al-Munawwarah on the night of 27 Ramadhan $1420 \mathrm{H}$. His departure was felt as a valuable gem loss.

The tireless struggle of his $d a^{\prime} w a h$, should be an example by future generations. He once told the young generation that the young Muslims who will lead the people in the future will need to be filled with knowledge, tazkiyah ruhiyah, fighting spirit and zuhûd nature of the world. Otherwise it will be easy and will be defeated in the face of the end time test. The expertise of the tongue in speech and the breadth of knowledge cannot give the best impression if not accompanied by a solid spiritual strength and istiqomah. 


\section{DISCUSSION}

In some of the terminology, it may be the concept of modernization of civilizations built by the West with technological indicators to be amazing. West with its unquestionable technology has been able to master the civilization of the world today because it is considered able to answer the challenges and demands of the modern world. However, as mentioned above the value that cannot be ignored sociologically, that in fact the West has a concept that is not completely to be followed, although the destination is also not entirely to be ignored. Al-Nadwî provides insightful views and ideas about how the concept of Islam in life. In some of his ideas, he does not give Misconceptions of the goodness of life with the advancement of technology and identity, but the value of the glorified modernity of the West has the building of cultural values which is 'misconception' with Islamic terminology. Al-Nadwî in this case also reveals that tribal wars and identity with the West can be seen from two perspectives; First, the defense of identity as a positive color, this view is expressed as an appreciation of the consistency of geographical dichotomy and western culture in maintaining the identity and even affect the surrounding civilization, as previously revealed that the West despite having areas that tend to have the same land but can still survive as an identity the substantial where the one with the other cannot be equated, Can we see for example Ireland who until now still do not want to join the UK although

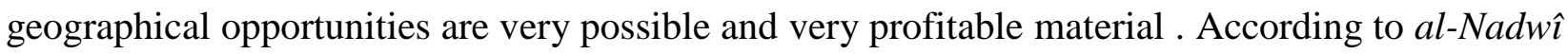
such a concept contains an Islamic value. A Muslim must be able to show his identity as a Muslim, preserving this identity is certainly not merely an identity in a literal sense, more than that, the identity that is meant is a terminological meaning that embodies the various values that emulate it. A Muslim should have an existence based on Islam (Alqran and Hadis). Islam as a value (identity) must be maintained in accordance with the indicators (arguments) in it. For example in terms of association, in terms of neighborhood, in terms of dress, including in terms of economic. Because in the true Islam through the value contained in it has contained a variety of teachings that are quite universal, including in the things mentioned above. Maintaining Identity as a Muslim the law must be done because that is part of the meaning of Islam itself as a 
theology (belief). Hence it is not surprising that $a l-N a d w \hat{\imath}$ reveals that 'maintaining identity is the first step to strengthening faith in Muslims. Secondly, Western identity is a negative meaning. The West does maintain its identity so that with that identity they proudly and stigmatized 'tilted' towards another identity. Al-Nadwî reveals that Islam does not teach so, Western modernism according to him should be responded proportionately because the teaching of identity contained in it is contains the value of Jahiliyyah where the people who no longer respect other people who are different. Islam teaches li ta'ârafu between humans amid the difference. Al-Nadwî reveals the West despite appearing with its stunning medal face, but it holds an undeniable dilemma, that in fact the West is not united in a strong (identity) relationship. They are in a separate conscience between one and the other with the boundaries of tribal egoism and material interests. This is according to al-Nadwî that in fact the West has been transformed into Jahiliyyah modern . Al$N a d w \hat{\imath}$ further explained that the recognition of identity should be in Islam with the proper terminology. Al-Nadwi reveals one offer is back to Islam. Islam is meant universally, including the reflection of its civilization. Long before the West which has been widely claimed to have modernized modernization, Islam actually has done that long before the 17th century. Al-Nadwi in this discussion exemplifies the history of the glory of Islam in the days of Khalîfah 'Umar bin' Abd al-'Azîz (717-720). Abul Hasan Ali al-Hasani al-Nadwî explains that humans can be united with the glue of religion that haq is the religion of Islam, not only for the Muslims itself, more than it covers the welfare of mankind, because Islam is revealed to all nature. One reflection which was then put forward by al-Nadwî is that along with the glory of Islam is also dragged the glory of his people universally which in turn is not only merely touch the Muslims themselves, but also by other people who are socially not to be distinguished. According to al-Nadwî, this kind of context is not visible from the civilization (modernization) of the West today, the modernization of the West according to him is colonized where progress adversely affects other identities. In examining identity and modernization, al-Nadwî offers several opinions, first formal approaches, two historical approaches, three social approaches, four economical approaches. In the formal order of Religion Islam has a source of teaching that becomes the frame of every movement, namely the Qur'an and Hadith. In the context of modernization and identity the 
Qur'an seems to have a not-so-small concept, in which the Qur'an for example contains fraternal values, trade terminology, association, marriage, dress, education, and the Qur'an also contain scientific values, health, and so forth. According to al-Nadwi, the Qur'an with its perfect content should be part of the foundation of living for a Muslim. The textuality of the verses on some sides may be clarified sociologically based on the practices shown by the Prophet Muhammad saw. In the context of modernity, there seems to be no doubt that the Prophet Muhammad with his teachings of Islam has managed to modernize Arabia. Practical life shown by the Prophet also becomes hand in hand that accompanies the content of the Qur'an.

Historical Approach; no doubt, Islam once 'lead the world'. If, for example, relate to the approach offered by al-Nadwi, then this historical approach can be traced in his book rijal al-fikr wa al-da'wah fì al-Islâm; in this book he introduces various figures who can be role models of a Muslim, such as 'Umar ibn' Abd al-Azîz, Hasan al-Basri, A'mad bin Hanbal, al-Ghazâlî,'Abd alQadir al-Jailânî, Jalâl al-Dîn al-Rûmî, Ibn Taimiyyah, Shah of the Trust Allâh al-Dahlawi, Aḥmad Sirhindî. In the muqaddimah part of this book he reveals a small conclusion that "Islam never thirsts mujaddid". According to al-Nadwî, the error is much seen from the Muslims themselves in choosing the wrong path. If the early Muslims dealt with the heresy and the conflict of understanding, then in modern times and millennia Islam confronted the more complex term of 'Jahiliyyah' culture Al-Nadwî advocated, in minimizing the impact of modernization of Western Jahiliyyah today, the regeneration of Muslims should be introduced to a clear historiography of Islam as a movement of civilization progress and assert that Western

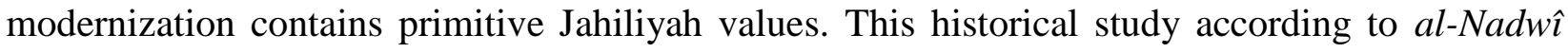
needs to be done in conveying the Islamic treasures of its existence. Al-Nadwi said in a social approach how much criticism is expressed against the West actually refers more to the social elements that are in it. Western culture according to al-Nadwî does not at all reflect Islamic fundamental values in any way. The historical fact mentioned by $a l-N a d w \hat{\imath}$ in his book, that more than 32,000 death penalties in Europe are burned alive. According to al-Nadwî, the unfair Law that Europeans applied to other nations seemed to portray enmity and eliminate the principle of justice which is the principle of a law, not just the classical era, this unfair legal fanaticism 
continues to be applied by the West in strengthening its power as a superpower medieval age. AlNadwî also provided a constructive critique of Western education. According to al-Nadwî, Western education led to the frost and decline of morality due to the loneliness of spiritual decline. Al-Nadwî also gave various analyzes that Western Education orientation is a lot of material, wants a high position and earn a large salary without implanting spiritual value. According to al-Nadwi, Western education is racing to become stronger and then with that power they make other nation tips slumped. Al-Nadwî in his book Imam 'Abd al-Qadir al-Jailânî reveals this condition by relating it to civilization in the time of al-Jailānî, he writes:

"... 'Abd al-Qadir al-Jailānî has witnessed what has been fall the lives of Muslims of his day. They live fragmented and hostile. Love of the world has dominated in addition to fighting for honor on the side of King and Sultan, man has turned to matter, position and power .. " In addition to his social criticisms of the West, al-Nadwî gave a fairly intense notion of social life. This is evident from the practices of daily life. Al-Nadwî in some facts, famous as people who closely associate with the community, as much expressed by the surrounding community as well as observations that once the author witnessed one example that al-Nadwî spelled out routinely provide material assistance to Muslims and non-Muslims after each prayer Asr at home, this assistance is expected to be given to 40 people. This phenomena as a form of bi al-hâl's preaching to non-Muslims to in turn see Islam as a potentially positive enough to follow.

This attitude as an orientation of the word of Allâh in Surat al-Baqarah:

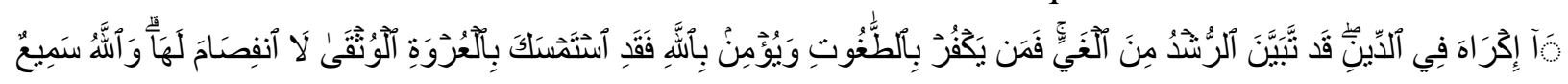
عَليٌْ. Meaning: "There is no compulsion to (enter) religion (Islam); in fact it is clearly the right path rather than a misguided path. Therefore, whoever denies Thaghut and believes in Allâh, then he has indeed held on to a very strong rope that will never break. And Allâh is Hearing, Knower, Knowing "(Q.S. al-Baqarah [2]: 256).

al-Nadwî in his ideas in his daily life towards non-Muslims is quite diplomatic in his book, madza typical al-'alam bi Nahtâti al-Muslimîn al-Nadwî quotes the Qur'anic verse: 
It means: "Those who believe fight in the cause of Allah, and those who reject Faith in the way of Thaghut, therefore fight the friends of Shaytaan, because in fact the deception of Satan is weak" (QS al-Nisa [4] : 76). Al-Nadwî reveals that wars are very close to the devil's demands. With him, the most appropriate $d a^{\prime} w a h$ for the present condition is by deeds (bi al-hâl), with which the best Islamic $d a^{\prime} w a h$ is to show a self-identity as a Muslim based on his teachings. Al-Nadwî criticized the social life that denied the concept of Hospitality, amid Western material progress, he saw no strong interpersonal unity among they so not infrequently neighbors do not know each other, do not help each other let alone visit each other. The concept that is in the Western stretcher is antisocial. One thing must also be known by the Muslims against the existence of the West, that they tend to ignore Religion, they do not know God, even Atheists. So social is often seen is social freedom, social relationships are free sex, pornography and so forth. According to al-Nadwî, Western westernization is very necessary to watch out for, the colonization of Western culture not only erode the culture of a nation but also even erode its Religion. Culture open aurat for example, it turns out that lately has become a term in the Muslim community which is a fashionable quibble. In fact, this contradictory fashion with Religion does not seem to be a banning by the clergy but instead tends to be silent to let it happen as a social necessity.

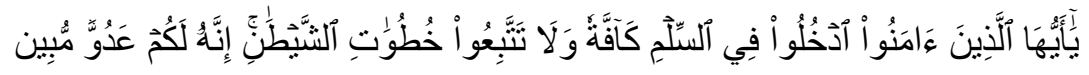

It means: "O ye who believe, enter you into the whole Islam, and do not join the steps of shaitan. Verily Satan is a clear enemy to you "(Q.S. al-Baqarah [2]: 208). The above verse is one of the principles in Islam where the concept of كآفة covers various elements in it ranging from social, educational, economic, and cultural. Western civilization actually teaches secularization. In the context of Indonesian, the secularization movement slowly begins to surface even though it is still with an unresolved face. In terms of education for example, Indonesia has created two systems where public education differs from Religious education, this system of education indirectly provides space for Islam to be called broad education, the Indonesian education system provides systemic limits for Islamic Education. In a more general context such as social life no 
longer reflects the true values of Islam. The Doctrinal Religion is no longer seen as a filter of the speed of Western culture to influence anyone. In the case of the clothing industry, for example, if Indonesia is mentioned as the largest Muslim community in the world, it should be at the same time Islam is rooted in the middle of society, but different analysis results precisely seen where more than the clothing industry in Indonesia is not according to Islamic law. In this order, Indonesian Muslim society may no longer be concerned with Islamic teachings or Islamic teachings have their own position that is not brought into the room of the (secularization).

\section{CONCLUSION}

According to al-Nadwi, secularization is a political movement, and in the history of this political movement was introduced by the West to strengthen its existence as an invader of civilization. In Islam the same term is also actually found, namely Islamization . Like the secularization of the West, Islamization has also triumphed in the world, the expansion of Islam into various quarters at the same time creating acculturation of Islam in the area, including in Indonesia. Islam accepts a civilization with a record not contrary to its teachings, and if it contradicts if there is a chance it will be in Islam culture. With this, Islam is an expansive religion, hence the acceptance of Western culture is a 'historical accident' to be avoided.

\section{REFERENCES}

al-Attas, Syed Muhammad Naquib. 1997. Islam and Secularism. Kuala Lumpur: ISTAC. . 1995. Prolegomena to the Metaphysics of Islam. Kuala Lumpur: ISTAC. . 1999. The Concept of Education in Islam. Kuala Lumpur: ISTAC. . 1995. The Prolegomena to the Metaphysics of Islam: an Exposition of the Fundamental Elements of the Worldview of Islam. Kuala Lumpur: ISTAC.

Ali Hasani Nadwi, Syed Abul Hasan. 1985. A Guidebook for Muslims. India: Nadwa PressNadwatul Ulama. 
. Education and Nurturing of Muslim Mass, Dapat diakses pada http:// www.muslim-library.com/?p=19926\&lang=English\&download_id=19926 . 1986. Islam and Civilizations. Tagore: Nahdatul Ulama-Academy of Islamic Research and Publications. 2005. Islam and the World: the Rise and Decline of Muslims and its Effect on Mankind, terj: Muhammad Asif Kidwai. Leicester: UK Islamic Academy, 2005. 1998. Islam: an Introduction. India: Academy of Islamic Research and Publications, 1998.

1989. Mankind's Debt to the Prophet Muhammad. England: Oxford Centre for Islamic Studies.

al-Mawdudi, Abu al'A'la. 1967. The Process of Islamic Revolution. Lahore: t.p al-Zayn, Syaikh 'Atif. 1989. Al-Islām wa Id̄̄yūlūjiyyyāt al-Insān. Beirut: Dar as-Syuruq, 1989.

Dimont, Max. 1962. Jews, God, and History. New York: The New American Libarary. . 1971. The Indestructible Jews. New York: The New American Library.

Graudy, Roger.1984. Janji-janji Islam, terj: H.M. Rasyidi. Jakarta: Bulan Bintang. http://kfip.org/dr-mohammad-natsir/ http://kfip.org/sayyid-abul-hasan-ali-al-hasani-al-nadawi/, diakses pada 28 Maret 2017, pukul 02.07 wib.

http://kfip.org/sayyid-abul-hasan-ali-al-hasani-al-nadawi/. http://kfip.org/wp-content/uploads/2014/01/Service-to-Islam-1980-

Abul-Hassan-Ali-Al-Nadawai-Mohammed-Natsir.pdf, diakses pada 28 Maret 2017, pukul 01.57 wib.

Ibn Athir, Ali. 1231. Al-Kamīl fì Tarikh. Vol. XIII. T.P. Lewis, Bernard. 1993. Islam and The West. New York: Oxford University Press.

Qutb, Sayyid. T.Th. Muqawwimāt al-Tasāwwur al-Islāmi. Beirut: Dar al- Syuruq.

Syam, Firdaus. 2007. Pemikiran Politik Barat: Sejarah, Filsafat, Ideologi, dan Pengaruhnya Terhadap Dunia Ke-3. Jakarta: Bumi Aksara. 
Toynbee, Arnold. T.Th. "Civilization on Trial”, dalam 'Western Civilization,' editor:

Somervell. Nottingham: International University Society.

Zarkasyi, Hamid Fahmy. 2016. "Islamic Worldview sebagai Paradigma Sains Islam" dalam "Islamic Science: Paradigma, Fakta, dan Agenda", editor: Syamsuddin Arif. Jakarta: INSISTS. 